Génét. Sél. Evol., 1985, 17 (2), 243-250

\title{
Genetic variation of flesh colour in canthaxanthin fed rainbow trout
}

\author{
J.M. BLANC and G. CHOUBERT * \\ I.N.R.A., Laboratoire d'Ecologie des Poissons et d'Aménagement des Pêches \\ Centre de Recherches hydrobiologiques \\ B.P. 3, Saint-Pée-sur-Nivelle, F 64310 Ascain \\ * I.N.R.A., Laboratoire de Nutrition et d'Elevage des Poissons, \\ Centre de Recherches hydrobiologiques \\ B.P. 3, Saint-Pée-sur-Nivelle, F 64310 Ascain
}

\section{Summary}

Genetic experiments were conducted using either random independent full-sib families ( 9 and 11 respectively) or sire-half-sib families (18) of rainbow trout who were fed an experimental diet supplemented with canthaxanthin. The resulting orange-red colour of the flesh from each fish was analyzed through spectrophotometry and expressed in standard terms of luminosity $(Y)$, dominant wavelength $\left(\lambda_{d}\right)$ and excitation purity $\left(\mathbf{P}_{\mathrm{e}}\right)$.

The following results were obtained :

- There is a substantial genetic variability among families in each colorimetric parameter. Estimated values of heritability from full-sib and from half-sib families do not differ significantly.

- Positive correlation between $\lambda_{d}$ and $P_{e}$, and negative correlations between $Y$ and $\lambda_{d}$ and between $\mathrm{Y}$ and $\mathrm{P}_{\mathrm{e}}$, are consistent with the pattern of canthaxanthin deposition in the flesh. Genetic correlations do not differ significantly from phenotypic ones.

- Pigmentation intensity is correlated to fish weight. This relationship, however, accounts for but a minor part of colour variation among market-size fishes.

Key words : Genetics, colour, canthaxanthin, salmonids.

\section{Résumé}

Variation génétique de la couleur de la chair chez la truite arc-en-ciel alimentée avec de la canthaxanthine

Des expériences génétiques ont été réalisées chez la Truite arc-en-ciel sur des familles aléatoires et indépendantes de pleins-frères (au nombre de 9 et 11) ou demi-frères de pères (18), alimentées par un régime expérimental supplémenté en canthaxanthine. La couleur de chair orange-rouge obtenue chez chaque poisson a été analysée par spectrophotométrie et exprimée en termes standards de luminosité $(Y)$, longueur d'onde dominante $(\lambda d)$ et pureté d'excitation $\left(\mathrm{P}_{\mathrm{e}}\right)$. Les résultats obtenus sont les suivants :

- Il y a une variabilité génétique notable entre familles pour chaque paramètre colorimétrique. Les valeurs d'héritabilité estimées à partir des familles de plein-frères et de demi-frères ne diffèrent pas significativement. 
- Les corrélations, positives entre $\lambda_{d}$ et $P_{e}$ et négatives entre $Y$ et $\lambda_{d}$ et entre $Y$ et $\mathbf{P}_{e}$, sont conformes au mode d'action de la canthaxanthine se déposant dans la chair. Les corrélations génétiques ne diffèrent pas significativement de leurs homologues phénotypiques.

- L'intensité de la pigmentation est corrélée avec le poids des poissons. Cette relation toutefois n'explique qu'une part minime de la variation de couleur chez des animaux de taille marchande.

Mots clés : Génétique, couleur, canthaxanthine, salmonidés.

\section{Introduction}

Pigmentation of the skin and flesh of trout and salmon is regarded as highly important by both fishermen and gastronomes, as well as by fish culturists seeking to improve the quality of their products. But besides their colouring activity itself, carotenoid pigments, which are the basis of salmonid pigmentation, would serve certain biological functions (TACON, 1981). These functions are generally not well known.

Fish are unable to synthesize this kind of pigment de novo. In some streams, and even more at sea, trout and salmon find carotenoids in planktonic crustaceans (SIMPSON et al., 1981) which give them a reddish colour (THOMMEN \& GLOOR, 1965). In hatcheries, it is necessary to include these pigments in the food. Since Deufel's first work (1965), fortification of the feed with synthetic canthaxantin ( $\beta, \beta$ carotene-4, 4'dione) is now usual practice (KoENIG, 1976).

Fish response to such diets was, however, found to be very variable, which led to interest in genetic variation. Differences of flesh colour were reported among strains (Besse, 1951) and among full-sib families (GJEDrem, 1976; Refstie \& Austreng, 1981), and heritability estimates were given by GJERDE \& GJEDREM (1984). Unfortunately, all these studies were performed on the basis of subjective scoring, therefore with limited precision, while spectrophotometric methods (CHOUBERT, 1982) appear more reliable.

The purpose of this study was to evaluate the heritability of flesh pigmentation among rainbow trout (Salmo gairdneri Richardson) sib-groups fed with canthaxanthin, by the use of spectrophotometric measurements.

\section{Material and methods}

Three experiments of the same kind (A, B and C) were conducted in consecutive years, using respectively 9, 11 and 18 families of Rainbow Trout (Salmo gairdneri R.). These families consisted of independent full-sib groups (exp. A and B) or sire-half-sib groups (exp. C) obtained from progeny testing experiments where these fish had been raised, in homogeneous environmental conditions, until averaging 130 to $150 \mathrm{~g}$ body weight.

From that point, in all experiments, the trout were fed to satiation, 4 times a day for 28 days, with an experimental feed containing $200 \mu \mathrm{g} / \mathrm{g}$ canthaxanthin given in its commercial presentation (pure product, 10 p. 100 hydrosoluble). This feed, free from any other carotenoid pigment, was in the form of $5 \mathrm{~mm}$ diameter pellets. 
In experiments $\mathrm{A}$ and $\mathrm{B}$, facilities consisted of compartmentalized rectangular tanks, each family (100 individuals) being randomly placed in a single compartment $\left(2 \mathrm{~m}^{2}, 0.40 \mathrm{~m}\right.$ water depth). Subsequently, in order to avoid a possible environmental effect due to the compartments, families in experiment $C$ were marked by fin-clipping 10 weeks prior to the beginning of the experimental feeding period, then placed together (1 200 individuals) in a large tank $\left(30 \mathrm{~m}^{2}, 0.40 \mathrm{~m}\right.$ water depth). In all experiments, tanks were supplied with spring water at $17^{\circ} \mathrm{C}$ constant temperature.

At the end of the experimental feeding period, random samples (4 trout in exp. A and B, 6 trout in exp. C) were collected from each family and killed. In experiment $\mathrm{C}$, individual sex and body weight $(\mathrm{g})$ were recorded. Latero-dorsal muscles were removed, frozen and kept at $-18^{\circ} \mathrm{C}$ until grinding immediately prior to analyzes.

Flesh colour evaluation and sample preparation were conducted using a Beckman spectrophotometer model DB equipped with an integrating sphere according to the procedure of CHOUBERT (1982). Reflectance values were treated in terms of CIE (1931) standards with illuminant $C$ as reference source (WYSZECKI \& STILES, 1967) and converted to values for luminosity $(Y)$, in p. 100 , dominant wavelength $\left(\lambda_{d}\right)$ in $\mathrm{nm}$ and excitation purity $\left(\mathrm{P}_{\mathrm{e}}\right)$, scaled in p. $100\left(100 \mathrm{P}_{\mathrm{e}}\right)$ for the sake of convenience.

Data were processed through classical methods of variance and covariance analysis (SNEDECOR \& COCHRAN, 1967). Heritability estimates and their standard-errors were obtained from the intra-class correlation coefficient $(\varrho)$, either among full-sib families $\left(\mathrm{h}^{2}=2 \varrho_{\mathrm{FS}}\right)$ or among half-sib families $\left(\mathrm{h}^{2}=4 \varrho_{\mathrm{HS}}\right)$, the difference between these two estimations providing a measure of common-environmental, maternal and nonadditive genetic effects (FALCONER, 1960). Genetic and phenotypic correlations and their standard-errors were computed according to SCHEINBERG (1966).

\section{Results}

As could be expected, the use of canthaxanthin supplemented diet resulted in a marked orange-red pigmentation of flesh, although with variable intensity depending on the experiment (table 1).

Differences in survival, weight or flesh colour between families within experiments showed no appreciable relationship with common environmental conditions, either compartment location (exp. A and B) or fin-clipping position (exp. C).

\section{A. Influence of sex and weight (experiment C)}

No significant influence of sex was found on any measurement of flesh-colour. Weight difference between males $(250 \mathrm{~g})$ and females $(233 \mathrm{~g})$ was significant $(\mathrm{p}=0.05)$. Dominant wavelength and excitation purity displayed significant regressions on weight (table 1), with slopes 0.0072 (s.e. : 0.0028) and 0.029 (s.e. : 0.010 ) respectively, and correlation coefficients as presented in table 2 , therefore accounting for but a minor part of colour variation. 
TABLE 1

Basic statistics of colour measurements and weight.

Statistiques des mesures colorimétriques et du poids.

\begin{tabular}{|c|c|c|c|c|}
\hline . & $\begin{array}{l}\text { Luminosity } \\
(\mathrm{Y})\end{array}$ & $\begin{array}{c}\text { Dominant } \\
\text { wavelength } \\
\left(\lambda_{\mathrm{d}}\right) \\
\end{array}$ & $\begin{array}{c}\text { Excitation } \\
\text { purity } \\
\left(100 \mathrm{P}_{\mathrm{e}}\right) \\
\end{array}$ & Weight \\
\hline \multicolumn{5}{|l|}{ A } \\
\hline No. $\ldots \ldots \ldots \ldots \ldots \ldots \ldots \ldots \ldots \ldots$ & 36 & 36 & 36 & \\
\hline Mean $\ldots .$. & 32.3 & 583.2 & 33.0 & \\
\hline Standard-deviation $\ldots \ldots \ldots$ & 3.34 & 1.16 & 3.73 & \\
\hline $\begin{array}{l}\text { Mean square } \\
\text { among FS families (a) } \ldots \ldots \ldots \ldots \\
\text { residual } \ldots \ldots \ldots \ldots \ldots \ldots \ldots\end{array}$ & $\begin{array}{c}25.35^{*} \\
6.98\end{array}$ & $\begin{array}{l}1.69 \\
1.24\end{array}$ & $\begin{array}{l}33.43^{*} \\
8.13\end{array}$ & \\
\hline \multicolumn{5}{|l|}{ B } \\
\hline No. $\ldots \ldots \ldots \ldots \ldots \ldots \ldots \ldots \ldots$ & 44 & 44 & 44 & \\
\hline Mean $\ldots \ldots \ldots \ldots \ldots \ldots \ldots \ldots \ldots$ & 28.0 & 580.6 & 31.6 & \\
\hline Standard-deviation $\quad \ldots \ldots \ldots \ldots \ldots$ & 5.32 & 1.13 & 3.29 & \\
\hline $\begin{array}{l}\text { Mean square } \\
\quad \text { among FS families (a) } \ldots \ldots \ldots \ldots \\
\text { residual } \ldots \ldots \ldots \ldots \ldots \ldots \ldots\end{array}$ & $\begin{array}{l}62.42^{*} \\
17.91\end{array}$ & $\begin{array}{l}3.02 * \\
0.73\end{array}$ & $\begin{array}{l}13.40 \\
10.02\end{array}$ & \\
\hline $\mathrm{C}$ & & & & \\
\hline No. $\ldots \ldots \ldots \ldots \ldots \ldots \ldots \ldots \ldots \ldots$ & 108 & 108 & 108 & 108 \\
\hline Mean $\ldots \ldots \ldots \ldots \ldots \ldots \ldots \ldots \ldots$ & 33.6 & 584.6 & 30.9 & 244.1 \\
\hline Standard-deviation $\quad \ldots \ldots \ldots \ldots \ldots$ & 3.42 & 1.24 & 4.36 & 40.72 \\
\hline $\begin{array}{l}\text { Mean square } \\
\text { regression on weight } \ldots \ldots \ldots \ldots \\
\text { among HS families (a) } \ldots \ldots \ldots \ldots \\
\text { residual } \ldots \ldots \ldots \ldots \ldots \ldots \ldots\end{array}$ & $\begin{array}{l}11.32 \\
16.08 \\
10.84\end{array}$ & $\begin{array}{c}13.98^{*} \\
3.09^{*} \\
1.09\end{array}$ & $\begin{array}{c}186.07^{*} \\
37.85^{*} \\
13.52\end{array}$ & $\begin{array}{l}2492.22 \\
1500.41\end{array}$ \\
\hline
\end{tabular}

(a) 8, 10 and 17 df in experiments A, B and C respectively.

* Significant $(P=0.01)$. 


\section{TABLE 2}

Estimates of heritabilities (diagonally), phenotypic correlations (below left) and genetic correlations (above right).

Estimation des héritabilités (diagonale), corrélations phénotypiques (en bas à gauche) et corrélations génétiques (en haut à droite).

\begin{tabular}{|c|c|c|c|c|}
\hline & Weight & Luminosity & $\begin{array}{l}\text { Dominant } \\
\text { wavelength }\end{array}$ & $\begin{array}{l}\text { Excitation } \\
\text { purity }\end{array}$ \\
\hline Weight $\ldots$. & {$[0.40 \pm 0.34]$} & {$[-0.20 \pm 0.73]$} & {$[0.50 \pm 0.40]$} & {$[0.37 \pm 0.43]$} \\
\hline Luminosity & {$[0.09 \pm 0.18]$} & $\begin{array}{l}(0.78 \pm 0.26) \\
{[0.29 \pm 0.32]}\end{array}$ & $\begin{array}{r}(0.08 \pm 0.36) \\
{[-0.61 \pm 0.39]}\end{array}$ & $\begin{array}{l}(-0.20 \pm 0.35) \\
{[-0.82 \pm 0.31]}\end{array}$ \\
\hline $\begin{array}{l}\text { Dominant } \\
\text { wavelength }\end{array}$ & {$[0.29 \pm 0.20]$} & $\begin{array}{r}(0.03 \pm 0.13) \\
{[-0.48 \pm 0.16]}\end{array}$ & $\begin{array}{l}(0.55 \pm 0.25) \\
{[1.00 \pm 0.42]}\end{array}$ & $\begin{array}{l}(0.62 \pm 0.26) \\
{[1.00 \pm 0.05]}\end{array}$ \\
\hline $\begin{array}{l}\text { Excitation } \\
\text { purity } \ldots . .\end{array}$ & {$[0.30 \pm 0.20]$} & $\begin{array}{l}(-0.44 \pm 0.11) \\
{[-0.58 \pm 0.13]}\end{array}$ & $\begin{array}{l}(0.56 \pm 0.09) \\
{[0.81 \pm 0.08]}\end{array}$ & $\begin{array}{l}(0.53 \pm 0.25) \\
{[0.95 \pm 0.42]}\end{array}$ \\
\hline
\end{tabular}

( ) : estimate \pm standard-error for experiments $A$ and $B$.

[ ] : estimate \pm standard-error for experiment $\mathrm{C}$.

\section{B. Heritability estimates and correlations}

Despite a lack of homogeneity (significant $p=0.01$ ) between luminosity residual mean squares from analogous (full-sib) experiments A and B (table 1), common estimates were computed by pooling the sums of squares and products, so as to be compared to experiment $C$ (half-sibs) estimates (table 2). It appears that the heritability estimated from full-sibs exceeds the corresponding value from half-sibs (as could be expected) in the sole case of luminosity, the differences being in the opposite direction for the 2 other colour measurements. None of these differences are significant.

It appears also as a general trend that experiment $\mathrm{C}$ provided higher correlations, whatever their signs, than $\operatorname{did} A$ and B. From phenotypic estimates, this trend is significant $(p=0.01)$ in the case of $Y-\lambda_{d}$ and $\lambda_{d}-P_{e}$ correlations. Genetic estimates, on the other hand, are not precise enough to allow these experimental differences to be statistically evidenced, nor do they differ significantly from the corresponding phenotypic estimates.

\section{Discussion and conclusions}

The main result of the present study, even though lacking precision because of limited sampling, is the evidence of a substantial genetic variability which may be 
compared to analogous recent findings. GJERDE \& GJEDREM (1984) used progeny-test nested designs (progeny nested within dam nested within sire) in rainbow trout and Atlantic salmon : quite similarly in both species, heritabilities estimated from the sire components were low and non-significant (in trout $: h_{s}^{2}=0.06$ with s.e. $: 0.08$ ) while significant estimates were drawn from the dam components (in trout : $\mathrm{h}_{\mathrm{D}}^{2}=0.28$ with s.e. : 0.09 ), therefore indicating noticeable maternal and/or non-additive genetic effects, which do not appear in the present study. It is however difficult to compare the above values of heritability with those reported in this study since they concern 2 different types of appraisals : subjective scoring and spectrophotometric measurements.

It has been established (CHOUBERT, 1982) that spectrophotometric methods are much more convenient for flesh colour assessment in trout. They are relatively simple and quick to operate, and they provide data which are consistent with visual perception although being more reliable than subjective scores. Such methods, yet, are not free from bias due to heterogeneity in colour or in surface condition of samples, which have to be handled and ground in a standardized way to ensure an adequate fidelity. This is especially important, since pigment concentrates better in the posterior part of trout muscle than in the anterior part (AUGER, 1973).

Chemical extraction and measurement of carotenoid pigments in the flesh is another valuable method, although much more cumbersome and time-consuming than colour assessment. This analytical method was used by Torrissen \& NAEvDAL (1984) whose results, based on a 13-sib-group nested design, show evidence of genetic differences. Besides, as demonstrated by CHOUBERT (1982), progressive deposition of canthaxanthin in the flesh induces a decrease of luminosity, an increase of dominant wavelength and above all an increase of excitation purity. The correlations estimated in the present study (strong positive correlation between $\lambda_{d}$ and $P_{e}$, weaker negative correlations between these parameters and $\mathrm{Y}$ ) therefore support the hypothesis that these colour variations result mainly from carotenoid level differences.

Individual sex and weight appear to have a rather little influence, even when significant, on flesh colour of grown-up fish. Differences between sexes among ripening adults were reported by KOENIG (1976), but not corroborated by other authors (GJERDE \& GJedrem, 1984 ; Torrissen \& Naevdal, 1984). Positive weight effect on pigmentation, on the other hand, was shown to be important in small fishes (50 to $150 \mathrm{~g}$ at the end of the experiment), but to diminish considerably in bigger ones (ABDUL-MALAK, 1975). Moreover, TORRISSEN \& NAEvdAL (1984) lastly reported a weak negative correlation between weight and level of carotenoids in adult fishes (averaging $2 \mathrm{~kg}$ ) ; as pointed out by these authors, differences in relative feed consumptions should be considered for a better understanding of the problem.

The rate of feeding should also be taken into account, its interactions with the genetic factors of pigmentation being unknown so far. The present study used marketsize (individual portion) trout raised in fresh water and fed a relatively high dose of canthaxanthin to ensure the pigmentation to be maximum within a month, while the optimal level, from an economic standpoint, is lower (ChOubert \& LuQuet, 1982). Comparable recent studies aiming at the estimation of pigmentation heritability were based on adult fish ( $2 \mathrm{~kg}$ or more) raised in sea cages and fed either shrimp waste (GJERdE \& GJEDREM, 1984) or low dose $(50 \mu \mathrm{g} / \mathrm{g})$ of canthaxanthin (TORRISSEN \& NAEVDAL, 1984), during a longer period of time (5 to 6 months). 
Moreover, differences observed among consecutive experiments in this study are indicative of uncontrolled factors which may interfere in fish culture and feeding as well as in sample preparation and colour assessment. For instance, nutritional constituents which are known to influence canthaxanthin fixation, such as lipids (ABDUL-MALAK, 1975) or carbohydrates (ReFstie \& AUSTRENG, 1981), may vary according to the formulation of the commercial diet to which canthaxanthin is added. Much remains to be learned about the comparative efficiencies of carotenoid feeding techniques, and about their consequences on the estimated genetic parameters.

\section{Acknowledgements}

The authors are indebted to F. HofFMANN-LA Roche and Co for their supply of canthaxanthin ; Dr. M. RENERRE (I.N.R.A., Meat Research Station) for his cooperation in providing the integrating sphere; R. Cescosse, Y. Hontang, R. Lanebere for the maintenance of the experimental animals.

Received December 22, 1983.

Accepted October 8, 1984.

\section{References}

AbDul-MalaK N., 1975. Influence de certains facteurs nutritionnels et écologiques sur le métabolisme d'un pigment caroténoüde : la canthaxanthine, chez la truite (Salmo gairdneri R.), 106 pp., Thèse Doctorat $3^{\mathrm{e}}$ cycle, Lyon.

AUger G., 1973. La canthaxanthine, son influence sur la coloration de la chair des truites. 112 pp., Thèse Doctorat Vétérinaire, Paris.

BEsSE P., 1951. La saumonisation artificielle des salmonidés, Truites et Saumons de fontaine. C.R. Acad. Sci. Paris, 233, 637-639.

Chovbert G., 1982. Method for colour assessment of canthaxanthin pigmented rainbow trout (Salmo gairdneri R.). Sci. Alim., 2, 451-463.

Choubert G., Luquet P., 1982. Fixation et rétention musculaire de la canthaxanthine par la truite arcc-en-ciel. Ann. Zootech., 31, 1-10.

Deufel J., 1965. Pigmentierungsversuche mit canthaxanthin bei Regenbogenforellen. Arch. Fisch. Wiss., 16, 125-132.

FALCONER D.S., 1960. Introduction to quantitative genetics. 365 pp., OLIVER \& BOYD, Edinburg.

GJedrem T., 1976. Possibilities for genetic improvements in Salmonids. J. Fish. Res. Board Can., 33, 1094-1099.

GJERDE B., GJEDREM T., 1984. Estimates of phenotypic and genetic parameters for carcass traits in Atlantic salmon and rainbow trout. Aquaculture, 36, 97-110.

Koenig J., 1976. Pigmentation de la Truite. Ann. Inst. Michel Pacha, 9, 31-44.

Refstie T., Austreng E., 1981. Carbohydrates in rainbow trout diets. III. Growth and chemical composition of fish from different families fed four levels of carbohydrate in the diet. Aquaculture, 25, 35-49.

SCHEINBERG E., 1966. The sampling variance of the correlation coefficients estimated in genetic experiments. Biometrics, 22, 187-191. 
Simpson K.L., Katayama T., Chichester C.O., 1981. Carotenoids in fish feeds. In : BAUERNFEIND J.C. (ed.), Carotenoids as colorant and vitamin $A$ precursors, 463-538, Academic Press, New York.

SNEDeCor G.W., Cochran W.G., 1967. Statistical methods. 6th ed., 535 pp., Iowa State University Press, Ames (U.S.A.).

TAcon A.G.J., 1981. Speculative review of possible carotenoid function in fish. Prog. Fish-Cult., 43, 205-208.

Thommen H., Gloor U., 1965. Zum Vorkommen von ketocarotenoiden in der Forelle. Naturwissenschaften, 52, 161-162.

Torrissen O.J., NAEvdal G., 1984. Pigmentation of salmonids-genetical variation in carotenoid deposition in rainbow trout. Aquaculture, 38, 59-66.

Wyszecki G., Stiles W.S., 1967. Color science. 628 pp., WileY J. and Sons, New York. 